\title{
Pengaruh Konsentrasi Larutan HF pada Proses Preparasi Terhadap Kadar Unsur Bahan Magnetik Pasir Besi
}

\author{
Abraham Laurens Rettob ${ }^{*}$, Martasiana Karbeka ${ }^{2}$ \\ ${ }^{1}$ Fakultas Keguruan dan Ilmu Pendidikan, Universitas Musamus, Merauke Indonesia \\ ${ }^{2}$ Fakultas Matematika dan Ilmu Pengetahuan Alam, Universitas Tribuana Kalabahi, Nusa \\ Tenggara Timur, Indonesia \\ *E-mail: abraham@unmus.ac.id
}

\begin{abstract}
Abstrak
Bahan magnetik (BM) pasir besi alam merupakan salah satu sumber adsorben magnetik. Selain BM, pasir besi alam juga mengandung bahan non-magnetik . Preparasi BM pasir besi dilakukan pada penelitian ini dengan tujuan untuk meningkatkan kadar unsur magnetik di dalamnya. Pasir besi alam yang digunakan berasal dari pesisir pantai Lansilowo. Preparasi dilakukan dengan pencucian menggunakan larutan HF dengan konsentrasi 0, 2, 5 dan 10\%. Hasil analisis kadar unsur dengan XRF menunjukkan bahwa unsur dominan pada pasir besi Lansilowo adalah $\mathrm{Fe}$ dan $\mathrm{Cr}$, yang merupakan unsur penyumbang sifat kemagnetan pada BM. Pencucian dengan larutan HF berbagai konsentrasi menyebabkan terjadinya perubahan kadar unsur pada BM. Semakin tinggi konsentrasi larutan HF mengakibatkan terjadinya peningkatan kadar Fe dan Cr total $(89,56 \%)$ serta penurunan kadar Si $(2,60 \%)$. Hasil penelitian menunjukkan bahwa konsentrasi larutan HF optimum yang digunakan adalah $10 \%$.
\end{abstract}

Kata kunci: bahan magnetik, larutan HF, pencucian

\begin{abstract}
Magnetic material (MM) of natural iron sand is one source of magnetic adsorbents. Natural iron sands also contain non-magnetic material. Iron sand MM preparation was carried out to increase the magnetic elements content in it. Natural iron sand used was from Lansilowo. Preparation of MM was done by washing it using HF solution with concentrations of 0, 2, 5 and $10 \%$. The XRF analysis indicated that the majority elements in Lansilowo MM are Fe and Cr, which contributed to magnetic properties in MM. The higher concentration of HF solution resulted in an increase of total $\mathrm{Fe}$ and $\mathrm{Cr}$ contents (89.56\%). It also decreased Si content (2.60\%). The result showed that the optimum concentration of HF solution used was $10 \%$.
\end{abstract}

Keywords: magnetic material, HF solution, washing

\section{Pendahuluan}

Adsorben merupakan salah satu material yang menjadi fokus para peneliti
(Khatibikamal dkk., 2019; Altun, 2019; Dognani dkk., 2019). Salah satu jenis adsorben yang menarik perhatian para peneliti adalah adsorben magnetik (Nuryono dkk.,2014; Rott dkk., 2018; Ma dkk., 2019).

6

Copyright @ 2019 WJC | ISSN 2621-5985 (online) | ISSN 2549-385X (print)

Volume 2, Nomor 1, 2019 
Adsorben magnetik memiliki keunggulan dibandingkan adsorben lainnya karena adsorben jenis ini lebih mudah untuk dipisahkan dari filtrat. Beberapa peneliti memperoleh adsorben magnetik melalui proses sintesis (Saksornchai dkk., 2018; Tahar dkk., 2018; Sebastian dkk., 2019). Peneliti lain memanfaatkan sumber daya alam yang ada sebagai sumber bahan magnetik (Rettob, 2018; Nuryono dkk., 2019). Adsorben magnetik yang berasal dari alam membutuhkan jumlah bahan kimia yang lebih sedikit dalam proses preparasinya dibandingkan dengan adsorben magnetik sintetis. Hal ini merupakan alasan perlu dikembangkannya adsorben magnetik berbasis alam.

Sifat kemagnetan suatu adsorben bergantung pada unsur yang terkandung didalamnya. Jika sebagian besar kandungan unsur pada adsorben adalah unsur yang memiliki sifat kemagnetan, maka adsorben tersebut memiliki sifat kemagnetan yang baik. Oleh karena itu, pada penelitian ini kandungan unsur pada bahan magnetik pasir besi alam dipelajari sebagai pengaruh perbedaan penggunaan konsentrasi larutan HF pada proses preparasi.

\section{Metode Penelitian}

\section{Alat dan Bahan}

Alat yang digunakan pada penelitian ini adalah beberapa peralatan gelas, oven, timbangan analitik, medan magnet eksternal, penggerus dan pengayak. Kandungan unsur BM pasir besi dianalisis dengan X-Ray Flourescence (PAnalytical Minipal 4).

Bahan magnetik pasir besi alam yang digunakan berasal dari pesisir pantai Desa Lansilowo Kecamatan Wawoni Utara Kabupaten Konawe Kepulauan Propinsi Sulawesi Tenggara. Bahan lain yang digunakan adalah akuades dan larutan HF (Merck).

\section{Prosedur Kerja}

Pasir besi dipisahkan dengan medan magnet eksternal kemudian diayak dengan ukuran 70 mesh. Padatan yang tertarik oleh magnet dicuci dengan akuades hingga bersih dan dikeringkan pada suhu $70-80^{\circ} \mathrm{C}$ hingga kering. Selanjutnya BM direndam dengan larutan HF konsentrasi 0, 2, 5 dan 10\%. Selanjutnya campuran tersebut disonikasi selama 15 menit. BM dipisahkan dari larutan dengan medan magnet eksternal dan dikeringkan pada suhu $70-80^{\circ} \mathrm{C}$ hingga kering. Padatan BM yang diperoleh dikarakterisasi dengan XRF.

\section{Hasil Penelitian dan Pembahasan}

Pasir besi awal mengandung bahan magnetik (BM) dan bahan non-magnetik. Oleh karena itu, dilakukan pemisahan dengan bantuan medan magnet eksternal. Bahan magnetik yang diperoleh digerus dan diayak dengan tujuan untuk memperoleh ukuran yang seragam. Selain itu, ukuran BM yang lebih kecil dapat meningkatkan luas permukaan BM sehingga mendukung perannya sebagai adsorben karena kemampuan adsorpsi yang lebih tinggi.

Preparasi BM dilakukan dengan menggunakan larutan HF. Larutan HF diketahui dapat melarutkan jumlah silika yang terkandung di dalam BM sehingga diharapkan dapat meningkatkan kandungan unsur yang berperan dalam memberi sifat kemagnetan. Konsentrasi larutan HF divariasi untuk mengetahui konsentrasi larutan $\mathrm{HF}$ optimum pada preparasi BM pasir besi Lansilowo ini. Metode sonikasi digunakan untuk mengoptimalkan proses pencucian BM pasir besi. Hal ini disebabkan adanya energi dari gelombang ultrasonik yang dapat mengefektifkan kontak antara BM dengan akuades maupun larutan HF.

Pengaruh konsentrasi larutan HF pada proses preparasi dengan kadar unsur diperlihatkan pada Tabel 1. Berdasarkan hasil analisis XRF tersebut, diketahui bahwa unsur dominan pada BM pasir besi Lansilowo adalah Fe dan Cr. Kedua unsur ini memiliki elektron yang tidak berpasangan pada orbital $d$. Elektron tak berpasangan tersebut dapat terpengaruh jika didekatkan oleh medan magnet. Inilah alasan BM pasir besi Lansilowo dapat tertarik magnet jika terdapat medan magnet eksternal. Oleh karena itu, BM pasir besi Lansilowo dapat digunakan sebagai adsorben magnetik. 
Silikon (Si) merupakan unsur terbanyak setelah Fe dan Cr. Pada umumnya, silikon berada pada fasa oksidanya dalam BM pasir besi (Prasdiantika, 2015). Berbeda dengan $\mathrm{Fe}$ dan $\mathrm{Cr}$, Si bersifat diamagnetik sehingga tidak tertarik dengan pengaruh medan magnet. Oleh karena itu, adanya unsur $\mathrm{Si}$ pada BM pasir besi dapat mengurangi sifat kemagnetan BM.

Tabel 1. Kadar Unsur pada BM

\begin{tabular}{lcccc}
\hline \multirow{2}{*}{ Unsur } & \multicolumn{4}{c}{ Kandungan (\%) } \\
\cline { 2 - 5 } & HF 0\% & HF 2\% & HF 5\% & HF 10\% \\
\hline $\mathrm{Fe}$ & 44,40 & 42,80 & 44,10 & 42,60 \\
$\mathrm{Cr}$ & 43,00 & 44,64 & 44,51 & 46,96 \\
$\mathrm{Si}$ & 4,30 & 4,20 & 3,40 & 2,60 \\
$\mathrm{Al}$ & 3,30 & 3,40 & 3,30 & 3,20 \\
$\mathrm{Mn}$ & 1,20 & 1,40 & 1,40 & 1,30 \\
$\mathrm{Bi}$ & 0,63 & 0,55 & 0,58 & 0,59 \\
$\mathrm{Ca}$ & 0,61 & 0,64 & 0,58 & 0,57 \\
$\mathrm{Ti}$ & 0,54 & 0,55 & 0,55 & 0,53 \\
$\mathrm{Re}$ & 0,48 & 0,46 & 0,44 & 0,59 \\
$\mathrm{Ni}$ & 0,34 & 0,32 & 0,29 & 0,30 \\
$\mathrm{Zn}$ & 0,27 & 0,28 & 0,28 & 0,26 \\
$\mathrm{Ir}$ & 0,25 & 0,27 & 0,27 & 0,32 \\
$\mathrm{~V}$ & 0,20 & 0,22 & 0,22 & 0,22 \\
$\mathrm{P}$ & 0,20 & 0,20 & 0,20 & 0,10 \\
$\mathrm{Ba}$ & 0,14 & - & - & 0,16 \\
$\mathrm{~K}$ & 0,07 & 0,06 & - & - \\
$\mathrm{Cu}$ & - & 0,07 & 0,05 & 0,06 \\
$\mathrm{Se}$ & - & - & 0,17 & - \\
\hline
\end{tabular}

Analisis kadar unsur dengan XRF membuktikan bahwa penggunaan larutan HF sebagai larutan pencuci BM pasir besi dapat mengurangi kadar Si yang terkandung di dalamnya. Semakin tinggi konsentrasi larutan HF maka kadar Si pada BM pasir besi semakin rendah. Kenaikan konsentrasi larutan $\mathrm{HF}$ juga mempengaruhi kadar unsur Fe dan $\mathrm{Cr}$ namun kedua unsur tersebut tetap menjadi unsur dominan pada BM dengan jumlah total berkisar $87-89 \%$. Hal ini menunjukkan bahwa pencucian BM pasir besi Lansilowo dengan larutan $\mathrm{HF}$ tidak mempengaruhi jumlah unsur yang memiliki sifat kemagnetan.

Berdasarkan hasil analisis XRF tersebut diketahui bahwa konsentrasi larutan HF optimum yang digunakan adalah $10 \%$. Hal ini dibuktikan dengan jumlah total $\mathrm{Fe}$ dan $\mathrm{Cr}$ tertinggi dibandingkan dengan penggunaan konsentrasi HF lainnya, yakni sebesar $89,56 \%$. Selain itu, jumlah Si yang terkandung di dalamnya lebih sedikit jika dibandingkan dengan penggunaan konsentrasi HF lainnya.

\section{Simpulan}

Penelitian ini memberi informasi bahwa unsur dominan pada BM pasir besi Lansilowo adalah $\mathrm{Fe}$ dan $\mathrm{Cr}$. Penggunaan larutan HF sebagai larutan pencuci BM pasir besi dapat mengurangi kadar $\mathrm{Si}$ yang merupakan salah satu sumber bahan nonmagnetik. Semakin tinggi konsentrasi HF maka semakin tinggi pula kadar total $\mathrm{Fe}$ dan Cr. Sebaliknya, kadar Si semakin berkurang jika konsentrasi HF meningkat. Hasil penelitian menunjukkan bahwa konsentrasi larutan $\mathrm{HF}$ optimum yang digunakan adalah $10 \%$.

\section{Daftar Pustaka}

Altun, T. 2019. Chitosan-Coated Sour Cherry Kernel Shell Beads: An Adsorbent for Removal of $\mathrm{Cr}(\mathrm{VI})$ from Acidic Solutions. J. Anal. Sci. 10(14), 1-10.

Dognani, G., Hadi, P., Ma, H., Cabrera, F.C., Job, A.E., Agostini, D.L.S. dan Hsiao, B.S. 2019. Effective Chromium Removal from Water by Polyaniline-Coated Electrospun Adsorbent Membrane. Chem. Eng. J. 372, 341-351.

Khatibikamal, V., Panahi, H.A., Torabian, A. dan Baghdadi, M. 2019. Optimized Poly(amidoamine) Coated Magnetic Nanoparticles as Adsorbent for the Removal of Nonylphenol from water. Microchem. J. 145, 508-516.

Ma, Y., Mu, B., Zhang, X., Xu, H., Qu, Z., Gao, Li., Li, B. dan Juanjuan, T. 2019. Ag$\mathrm{Fe}_{3} \mathrm{O}_{4} @ \mathrm{rGO} \quad$ Ternary Magnetic Adsorbent for Gaseous Elemental Mercury Removal from Coal-Fired Flue Gas. Fuel. 239, 579-586.

Nuryono, Muliaty, E., Rusdiarso, B., Sakti, S.C.W. dan Tanaka, S. 2014, Adsorption of $\mathrm{Au}(\mathrm{III}), \mathrm{Cu}(\mathrm{II})$ and $\mathrm{Ni}(\mathrm{II})$ on Magnetite Coated with Mercapto Groups Modified Rice Hull Ash Silica. J.Ion Exchange. 25(4), 114121. 
Nuryono, Rosiati, N.M., Rettob, A.L., Suyanta dan Arryanto, Y. 2019. Coating of 2 Aminobenzimidazole and 1-(oTolyl)biguanide Functionalized Silicas on Iron Sand Magnetic Material for Sorption of $\left[\mathrm{AuCl}_{4}\right]^{-}$. Indo. J. Chem. 19(2), 395-404.

Prasdiantika, R. 2015. Sintesis Hibrida Propildietilentriamin-Silika Terlapis pada Bahan Magnetik Pasir Besi untuk Adsorpsi Au(III). Tesis, tidak dipublikasikan, Universitas Gadjah Mada.

Rettob, A.L., Nuryono, N., Pasaribu, Y.P., Buyang, Y. dan Waremwa, R.S. 2018. Adsorption of $\left[\mathrm{AuCl}_{4}\right]^{-}$on Iron Sand Magnetic Material Coated with Aminnobenzimidazol Modified Silica. Atlantis Highlights in Engineering (AHE), 1, 277-280.

Rott, E., Nouri, M., Meyer, C., Minkle, R., Schneider, M., Mandel, K. dan Drenkova-Tuhtan, A. 2018. Removal of Phosphonates from Synthetic and Industrial Watewater with Reusable
Magnetic Adsorbent Particles. Water Res. 145, 608-617.

Saksornchai, E., Kavinchan, J., Thongtem, S. dan Thongtem, T. 2018. Simple WetChemical Synthesis of Superparamagnetic CTAB-Modified Magnetite Nanoparticles Using as Adsorbents for Anionic Dye Congo Red Removal. Mat. Lett. 15, 138-142.

Sebastian, A., Nangia, A. dan Prasad, M.N.V. 2019. Cadmium and Sodium Adsorption Properties of Magnetite Nanoparticles Synthesized from Hevea brasiliensis Muell. Arg. Bark: Relevance in Amelioration of Metal Stress in Rice. J. Hazard. Mater. 371(5), 261-272.

Tahar, L.B., Oueslati, M.H. dan Abualreish, M.J.A. 2018. Synthesis of Magnetite Derivatives Nanoparticles and Their Application for the Removal of Chromium(VI) form Aqueous Solutions. J. Colloid Interf. Sci. 512, 115-126. 